\title{
DO FINANCIAL REPORTING QUALITY AND CORPORATE GOVERNANCE HAVE RECURSIVE SIMULTANEOUS EFFECT? EVIDENCE FROM INDONESIAN MANUFACTURING COMPANIES
}

\author{
Dianwicaksih Arieftiara \\ Universitas Negeri Surabaya \\ dianwicaksih@unesa.com \\ Sidharta Utama \\ Universitas Indonesia \\ sidharta.utama@ui.ac.id
}

Received: 07-11-2017

Revised: $15-04-2018$

Accepted: 22-04-2018

\section{ABSTRACT}

Financial reporting reflects transparency of the firm and if it could not explain the changes in shareholders' value in a timely manner; shareholders need additional monitoring mechanism. This study aims to investigate the effect of financial statements' quality on corporate governance mechanism and to examine the recursive simultaneous effect between both. This study uses earnings timelines as a proxy of financial reporting's quality; proportion of independent board and board size as proxies of corporate governance mechanism. Using Two Stage Linear Regression (TSLS) and samples consist of manufacturing companies listed on Indonesian Stock Exchange (IDX) in 2015, this study finds that earnings timelines have significant influence on board size; earnings timelines and proportion of independent board have the recursive simultaneous effect; however, it fails to document the recursive simultaneous effect of earnings timelines and ownership concentration. This study is the first that investigates the recursive simultaneous effects of financial reporting quality and corporate governance.

Keywords: Corporate governance; Earnings timelines; Ownership concentration, Quality of financial reporting; Transparency.

\section{ABSTRAK}

Pelaporan keuangan mencerminkan transparansi perusahaan dan jika tidak dapat menjelaskan perubahan dalam nilai pemegang saham secara tepat waktu; pemegang saham membutuhkan mekanisme pemantauan tambahan. Penelitian ini bertujuan untuk menyelidiki pengaruh kualitas laporan keuangan pada mekanisme tata kelola perusahaan dan untuk menguji efek simultan rekursif antara keduanya. Penelitian ini menggunakan rentang waktu penghasilan sebagai proxy kualitas pelaporan keuangan; proporsi ukuran dewan dan dewan independen sebagai proksi mekanisme tata kelola perusahaan. Dengan menggunakan Two Stage Linear Regression (TSLS) dan sampel terdiri dari perusahaan manufaktur yang terdaftar di Bursa Efek Indonesia (BEI) pada tahun 2015, penelitian ini menemukan bahwa jadwal pendapatan memiliki pengaruh signifikan terhadap ukuran dewan; jadwal penghasilan dan proporsi dewan independen memiliki efek simultan rekursif; Namun, gagal untuk mendokumentasikan efek simultan rekursif dari garis waktu penghasilan dan konsentrasi kepemilikan. Penelitian ini adalah yang pertama yang menyelidiki efek simultan rekursif dari kualitas pelaporan keuangan dan tata kelola perusahaan.

Kata Kunci: Tata kelola perusahaan, Jadwal penghasilan, Konsentrasi kepemilikan, Kualitas pelaporan keuangan, Transparansi.

How to cite: Arieftiara, D., \& Utama, S. (2018). Do Financial Reporting Quality And Corporate Governance Have Recursive Simultaneous Effect? Evidence From Indonesian Manufacturing Companies. 9 (2): 168-185.doi: http://dx.doi.org/10.26740/jaj.v9n2.p168-185 
Arieftiara, Utama, Do Financial Reporting Quality...

\section{INTRODUCTION}

Corporate governance becomes the basic attention of corporation and stakeholders particularly for shareholders. Previous literatures had explained that corporate governance as a mechanism which used by shareholders to control the people inside the firm and by management in order to protect their interests (La Porta et al., 2002). Effective corporate governance will improve firm's performance; therefore it will bring benefits for shareholder. Chi (2009) found that overall firms' performance positively related with disclosure quality, this indicates that transparency, as an indicator of disclosure quality, is as a set of corporate governance mechanism which leads to better firms' performance.

Corporate transparencies and full disclosure of information are not only as the main attributes of corporate governance mechanism (OECD, 1999), but also as the most important factor of corporate governance's quality. According to Bushman et al. (2004), there are two factors that affect corporate transparencies, i.e. (1) uninformative financial accounting systems characterized by the inability of firms' GAAP earnings to explain changes in shareholder value in a timely fashion (low earnings timeliness) and; (2) firm complexity due to extensive geographic and/or line of business diversification. Bushman et al. (2004) posited that limited corporate transparency increases demands on corporate governance systems to alleviate moral hazard problems resulting from a more severe information gap between managers and shareholders, ceteris paribus. Furthermore, Bushman et al. (2004) investigated whether earning timelines and firm complexity affect corporate governance system. They found that corporate governance system which proxied by ownership concentration, directors' and executives' stock-based incentive; negatively related to earnings timelines. They also found that ownership concentration and directors' stock-based incentives increases along the firm complexity.

This study contributes on continuing the research of Bushman et al. (2004) that focused on the effects of accounting reporting on corporate governance, however they did not consider the causal-effect relationship between corporate governance structures and the properties of accounting numbers through manager's discretion on choosing the accounting policies and earnings management activities.

Previous studies on U.S context about corporate governance effectiveness in firm monitoring were inconclusive. Bushman et al. (2004) found that earnings timelines have no significant relationship with the proportion of outside directors. Vafeas (2000) also found that proportion of outside directors has no significant relationship with earnings informativeness. Conversely, Petra (2006) found that proportion of outside directors positively affects earnings informativeness and accounting quality as well. Dimitropoulos and Asteriou (2010) found that 
AKRUAL: Jurnal Akuntansi, volume 9, nomor 2, April 2018,

the number of outside directors positively related to quality of earnings information; they also found that Board of Directors' (BOD) independencies are strongly associated with quality and value relevance of accounting data or published financial reports; however board size has no relation to the value relevance of accounting earnings. Moreover, Dimitropoulos and Asteriou (2010) documented that firms with the higher number of outside directors more timely when recognizing bad news condition; there were no incremental increases in speed of recognizing good news in earnings for the firm with increased board independence.

Previous studies on relationship of corporate ownership and financial reporting quality provide various evidences. Ball and Shivakumar (2005) found that on average, private firms in U.K have lower earnings quality than public firms. Burgstahler et al. (2006) found evidence that public ownership firms have higher earnings quality since they have lower tendencies to manage earnings than private ownership firms. Conversely, Beatty et al. (2002) found that public ownership firms have lower earnings quality since they have greater tendencies to manage earnings than public ownership firms. Givoly et al. (2010) found that accounting numbers of public ownership firms have less persistence accruals and have more estimation errors; these indicate the possibility of earnings management. They also found that public firms' financial reporting are more conservative (in terms of timely loss recognition) compared to private firms.

In Indonesia, there has been no study conducted regarding the effect of financial reporting quality on corporate governance mechanisms. However, previous studies in Indonesia have explained that corporate governance affects quality of financial reporting (i.e. earnings quality), earnings management activities, firms' performances, etc. Susanto and Siregar (2012) investigated the effect of corporate governance mechanism on financial reporting quality and found that corporate governance (i.e. audit committee effectiveness) positively affects financial reporting quality. Furthermore, board effectiveness and auditor size have no significant influence on earnings quality.

Ownership concentration can be used for internal disciplinary mechanisms for management: it can increase the effectiveness of monitoring. Shareholders who have large ownership of firm's shares have information access to reduce the asymmetry information with managers. Alimehmeti and Paletta (2012) find that ownership concentration has positive relation with firm value (measured by ROA). Specifically in Indonesia which has low legal protection, ownership concentration is become main corporate governance mechanism. Relationship of ownership structure and financial reporting quality in Indonesia show various evidences. Nuryaman (2009) found that ownership concentration positively influence the 
Arieftiara, Utama, Do Financial Reporting Quality...

voluntary disclosure. This result indicates that firms' value can be reflected from accounting numbers. Nuryaman (2008) also found that ownership concentration negatively influence earnings management. Ownership concentration can monitor managers' activity so that it can reduce earnings management, in turn it can increase the quality of reported earnings. Conversely, ownership concentration negatively related to financial reporting quality, which measured by earnings informativeness (Wawo, 2010).

Indonesia adopts a dual board in its internal organizational structure, the functions of the board are separated, i.e. policy making; controlling and monitoring functions. Policy making is held by directors, while the function of controlling and monitoring are held by the board of director (Wardhani \& Joseph, 2010). Siregar and Utama (2006) find that number of board of director not related to firms earnings management. Conversely, Kusumawati and Riyanto (2005) find that number of board positively related to firms value, measured by stock market value. Earnings management and stock market value are financial reporting quality attributes. This both of researches implied result gap on relationship between board and financial reporting quality.

From description above, also to continue Bushman et al., (2004) as well, this research aimed to investigate the recursive simultaneous effect between financial reporting quality, corporate governance mechanisms and ownership concentration in the Indonesian context. Expected contribution from this research is to provide empirical evidence that financial reporting quality has recursive simultaneous relationship with corporate governance and ownership concentration in Indonesia. This research uses the time period of the board member being a member in the same firms' board as a measure of board independency.

\section{LITERATURE REVIEW}

According to the agency theory, agency problems arise because of information asymmetry occurs between managers and shareholders. Shareholders require that managers' activity is intended to maximize their wealth. Shareholders have limited information to ensure that managers always act in order to increase their wealth. However, managers have more information about decision making of accounting policy choice than shareholders. Therefore, shareholders need a corporate governance mechanism to monitor all managers' activities. Corporate governance mechanism also as a tool to increase the accountability of managers in whole process running the firm, include formulating, implementing and evaluating strategy. In addition, corporate governance mechanism can also increase the transparency of the achievement of managers' work. 
AKRUAL: Jurnal Akuntansi, volume 9, nomor 2, April 2018,

Earnings Timelines as a Measure of Firm Financial Reporting Quality

Earnings timelines is one dimension of firm financial reporting quality. Fanani (2009) explaines that financial reporting quality consists of 3 attributes, they are: value relevance, timelines, and conservatism. Fanani (2009) states that financial reporting quality is a researchable construct in two ways, first, financial reporting quality related to cash and earnings. If reported current earnings can be a good indicator for future firm earnings, then this financial reporting has good quality. Dechow and Dichev (2002) explain that, first, financial reporting has a good quality if reported earning has strong associate with future operating cash flow. Second, financial reporting quality is higher when it relates to stock return, has stronger relationship between earnings and stock return. This implied that financial reporting quality can be assessed through market attributes, i.e.: value relevance, timelines and conservatism.

\section{Earnings Timelines Influence Corporate Governance Structure}

Shareholders need good quality of firm financial information in order to ensure the safety of their investment. Sloan (2001) investigates the role of accounting information toward corporate governance mechanism and finds that accounting information is an important input for major mechanism of corporate governance. Furthermore, Sloan (2001) explains that accounting information indicate whether corporate governance mechanism to improve accountability of management is needed for stakeholders interest.

Bushman et al. (2004) argue that the extent to which current accounting numbers capture the information set underlying current changes in value (i.e., earnings timeliness) is a fundamental determinant of their governance value to directors and investors. Directors monitor managerial and firm performance, ratify managerial decisions, provide managerial incentives, and aid in strategic planning activities (e.g., strategy development, succession planning). To carry out these duties, directors demand information to help them understand how and why equity values are changing. Outside investors and financial analysts who monitor managerial and firm performance also demand such information. Stock prices provide information about overall changes in equity value.

Earnings timeliness measures the extent to which current earnings capture the information set underlying contemporaneous changes in stock price. Based on information quality attribute, earnings information has high quality if it can capture the changes on stock prices better. High earnings quality is produced by earnings timelines. Firms need costly monitoring mechanisms or specific knowledge gathering to substitute for low earnings timeliness (Bushman et al., 2004). Bushman et al. (2004) find that corporate governance structure (proxied by high

Copyright @ 2018 AKRUAL: Jurnal Akuntansi 
Arieftiara, Utama, Do Financial Reporting Quality...

ownership concentration; directors' and executives' equity-based incentive; and board structure or outside board reputation) vary inversely with earnings timelines.

Directors' and executives' equity-based incentive data are not available in Indonesia, therefore, this research focuses on ownership concentration and board structure. Ownership concentration has power and resources to monitor the firm. If firm reports earnings information timely, this means that shareholders believe that firm has adequate transparency. Conversely, if earnings information cannot capture the changes in stock price (not timely), shareholders must add their ownership to gain more control to the firm. Based on briefly explanation above, we predict that earnings timelines cause variation on ownership concentration, and the first hypothesis would be as follow:

H1a: Earnings timelines have a negative effect on ownership concentration.

Bushman et al., (2004) find that earnings timelines has negative influence toward board structure, measured by number of outside director which also as board member in other firm (board reputation). Wardhani and Joseph (2010) explain that Indonesia pursues dual system board in internal organizational structure, which there is a separation of board function, policy decision making and monitoring function. Policy decision making function is held by directors, meanwhile monitoring function is held by board of director (commissionaire). Board of director (board) establishes an audit committee to do their function. Audit committee must consist of at least one independent board member. To achieve the audit committee's goals, board can ask from outside party with various skills, experiences and other competencies as a member of audit committee. Audit committee must be independent, free from directors'; external auditors'; and managers' influences, therefore, it only responsible to the board.

Based on finding of Bushman et al. (2004) and concern with Indonesian context, therefore, board structure in this research is proportion of independent board and board size. We purpose the next hypotheses as follows:

H1b: Earnings timelines have a negative effect on proportion of independent board.

H1c: Earnings timelines have a negative effect on board size.

\section{Corporate Governance as Determinants of} Firm Financial Reporting Quality

According to agency theory concept, corporate governance mechanism believed can decrease agency problems that occur between shareholders and management (La Porta et al., 2002). Board of director has important role in monitoring management and establishing a mechanism that align executive and shareholders interest (Armstrong, 2010). In order to monitor effectively, board must be independent from management adequately (Armstrong et al., 2010). 
AKRUAL: Jurnal Akuntansi, volume 9, nomor 2, April 2018,

\section{Ownership Concentration and Earnings Timelines}

Ownership concentration has influence to level of earnings timelines. If ownership concentrated on outside shareholder, they have not adequate information access than inside ownership so that the only information source they have is from financial statement. In consequence, firm must able to provide timely accounting information. Conversely, if ownership concentrated on inside shareholder, they have better private information about firm financial condition than outside shareholder. Therefore inside ownership don't need timely financial information/reporting (Armstrong, et. al., 2010).

Evidence from research conducted in Korea is earnings informativeness higher along with majority ownership (blockholders) and higher percentage of main ownerstock ownership, beside that earnings informativeness is higher as well (Jung \& Kwon, 2002). Ownership structure in Korea is dominated by one single main owner that involved in firm management. Based on research about ownership separation and control in Asia, Indonesia and Korea have same characteristic, i.e. ownership structure dominated by single main owner (Claessens et al., 2000).

In Indonesia context, Rachmawati and Triatmoko (2007) find that ownership concentrated on institution positively influence on firm value measured by Price to Book Value (PBV). Fanani (2009) explains that firm value reflected from its stock price and earnings information has high quality if it can capture better changes in the stock price. This result indicates that firms' value can be reflected from accounting numbers. Nuryaman (2009) find that ownership concentration is positively influence the voluntary disclosure. Nuryaman (2008) also find that ownership concentration is negatively influence earnings management. Ownership concentration can monitor managers' activity so that reduce the earnings management, in turn it can increase the quality of reported earnings. Thus, the next hypothesis as follows:

H2a: Ownership concentration has a positive effect on earnings timelines.

\section{Board Structure and Earnings Timelines}

In American context, board structure consists of inside and outside directors. Linck et al. (2008) document that in their median sample research, board structure consist of $67 \%$ outside director (independent director). Outside directors generally are skilled professionals, such as CEO and executive from outside the company, that have various background such as politician and regulators, Dean and University Rector, and success businessman. The benefit having skilled professionals as outside directors is they can give important advices such as business, financial, marketing, operation strategy and organization structure. Their independencies enable them to monitor manager behavior objectively and set rational expectancy of managerial performance. 
Arieftiara, Utama, Do Financial Reporting Quality...

Inside directors are generally the firm executives. They can facilitate effectively decision making since they know all information of the firm, understand the firm's strengths and weaknesses (they have private information). Inside and outside directors both have advantage and disadvantages. Inside directors can provide information or knowledge about firm activities to outside director (Fama \& Jensen, 1983). However, inside directors which have greater firm's shares will have greater interest to maximizing shareholders value (Armstrong, et al., 2010).

Furthermore, the domination of inside directors potentially causes a conflict in undertake monitoring function-since they are not independent from firm's CEO, and also they have interest to protect their wealth. Adams and Ferreira (2007) argue that when board structure consists of inside and outside director, inside director will give private information to the outside director, so that well informed outside director tend to give effective advice to the CEO. However, inside director will not give any private information if he involved in CEO's strategic decision-making. We can conclude that if board structure dominated by insider director, the board is not need timely earnings information to support its function-since insider director has inside information.

Indonesia adopts a dual board system in its internal organizational structure, where the board are separated. Policy decision making function is held by directors, monitoring/ controlling function is held by board of director (commissionaire). Board of directors may establish an audit committee to assists them carry out their functions. The audit committee members are required to at least one independent director. Board may ask the outside, with a range of expertise, experience, and other skills needed, as a member of the audit committee in order to achieve the objectives of the audit committee. The audit committee should be free from the influence of directors, external auditors, and managers, the audit committee is responsible only to the board of director (Wardhani \& Joseph, 2010).

Felo et al. (2003) find that audit committee independency positively related to financial reporting quality. Chan and $\mathrm{Li}$ (2008) find that independent audit committee can increase firm's value. Suranta and Puspa (2005) find that interaction between proportion of independent board and earnings information positively related to stock return. Suranta and Puspa (2005) also find that firm's board structure (through its monitoring function) affects financial reporting quality. Based on explanations above, the next hypothesis is as follows:

H2b: Proportion of independent board has a positive effect on earnings timelines.

Kusumawati and Riyanto (2005) find that board size (number of board member) positively related to firm's value. They used market share value as proxy of firm's value. Fanani (2009) explains that from information quality attributes, 
AKRUAL: Jurnal Akuntansi, volume 9, nomor 2, April 2018,

earnings information has high quality (timely earnings information) if it can capture better changes in the stock price. Based on those, we purpose our next hypothesis as follow:

H2c: Board size has a positive effect on earnings timelines.

\section{RESEARCH METHODOLOGY Sample and Data}

Sample consist of all manufacturing firm which has all data needed in Indonesia Stock Exchange (IDX). Sampling criteria is firm has all data needed in research. There are 144 firms listed on IDX at 2011. Firms with complete data available (i.e. stock price data from 2010 to 2011) are 140 firms. Exclude from sample is firm with positive or negative return for 3 periods (2010-2015); or firm with positive/negative only for 1 period from 2010-2015, since it cannot be regressed to find the component value of earnings timelines (near singular metrics). We exclude 9 firms. Finally the sample is 131 firms.

We use data from 2010-2015 for earning timelines variable, for other variables we used period 2015 only. Data are taken from firm annual report, Indonesia Capital Market Directory (ICMD), and data stream.

\section{Variable Operational Definition}

\section{a. Earnings timelines (EARN_TIMELY)}

Earnings timelines is as a proxy of financial reporting quality, is a level that shows the extent of accounting numbers capture the changes of equity value (Fanani, 2009). We follow Bushman et al. (2004) to measure 176
EARN_TIMELY. Bushman et al. (2004) developed timeliness metric to measure EARN_TIMELY. This metric aggregates three firm-specific metrics. The first two metrics are based on firm-specific regressions of annual earnings on contemp-oraneous stock returns over a period of at least 5 years beginning in 2010 and ending in 2015 (this metrics derived from Basu (1997) regression model) as follows:

$$
\begin{gathered}
\text { EARNt }=\mathrm{a} 0+\mathrm{a} 1 \mathrm{NEGt}+\mathrm{b} 1 \quad \mathrm{RETt}+ \\
\mathrm{b} 2 \mathrm{NEGt} * \mathrm{RETt}+\mathrm{e}
\end{gathered}
$$

Where:

EARN $_{t}=$ "core" earnings of a given firm in year $\mathrm{t}$, defined as earnings before extraordinary items, discontinued operations, and special items, deflated by the beginning of year market value of equity

$\mathrm{RET}_{\mathrm{t}}=$ the 15-month stock return ending 3 months after the end of fiscal year $\mathrm{t}$

$\mathrm{NEG}_{\mathrm{t}}=$ dummy variable equal to 1 if $\mathrm{RET}_{\mathrm{t}}$ is negative and 0 otherwise.

This specification allows b1 to capture the speed with which good news in a firm's stock returns is reflected in earnings, while b1 and b2 captures the speed with which bad news is reflected in earnings. Our first metric is b1; which measures the relative speed with which firms' earnings reflect good news. Our second metric of the timeliness of earnings is $\mathrm{R} 2$ from Eq. (1), which, as observed by Ball et al. (2000), is decreasing in the lag with which earnings capture the news reflected in stock returns.

Our third metrics is R2 from firm-specific regression of earnings changes on contemporaneous stock return over a period of at Copyright @ 2018 AKRUAL: Jurnal Akuntansi 
Arieftiara, Utama, Do Financial Reporting Quality...

least 5 years beginning in 2010 and ending in 2015 (we called this model as ERC model):

$\mathrm{RETt}=\mathrm{a} 0+\mathrm{b} 1 \mathrm{EARNt}+\mathrm{b} 2 \Delta \mathrm{EARNt}+\mathrm{et}$

where RETt and EARNt are defined as before, and $\triangle \mathrm{EARNt}$ is the change in core earnings from year $t-1$ to year $t$; deflated by the market value of equity at the beginning of year $\mathrm{t}$.

Following Bushman et al. (2004), we refer to the slope estimate from Eq. (1) (i.e., b1) as REV_SLOPE; R2 from Eq. (1) as REV_R2; and R2 from Eq. (2) as ERC_R2. From these three individual metrics (REV_SLOPE; REV_R2; and ERC_R2), we develop a composite index as our primary metric of the timeliness of earnings. We calculate the percentile rank for each firm in the sample for each of the three metrics. The composite timeliness metric for a given firm, EARN_TIMELY; is computed as the average of all three percentile rank values.

\section{b. Ownership Structure (OWN)}

We use ownership concentration as a proxy of ownership structure. Based on Nuryaman (2008) ownership concentration is majority of firm's shares are held by a minority of individuals/groups, so that individuals or groups have a relatively dominant number of shares compared to other shareholders. We use percentage of largest shareholdings by individuals/groups as a measure of concentration of ownership.

\section{c. Proportion of independent board (IND)}

Proportion of independent board (IND) computed as number of independent board member divided by total board member (Siregar
\& Utama, 2006). We use length period of the board member become a member of board in the same firm (for maximum 9 years) as independent criteria.

\section{d. Board Size (BOD)}

Board size is a number of all board member (Siregar and Utama, 2006).

\section{e. Control variables}

We use some control variables that have significant effect on Bushman et al. (2004) and we add some variables in Indonesia context. Control variables are LOG_ASET (natural logarithm of total asset); LEV (leverage, i.e. total debt deflated by total asset); and GROWTH (firm growth, measured by net sales growth). We also use FIRM_AGE (length of period firm operates, in years) to control the equation which corporate governance variable as an endogen; and PAF (size of accounting public firm, has value 1 if big four, 0 otherwise) to control the equation which corporate governance as an exogenous.

\section{Empirical Model}

We use Two Stage Linear Regression (TSLS) to test the hypotheses, since we hypothesized that there are recursive simultaneous effect between independent and dependent variables. Based on Bushman et al. (2004), we use model (3), (4), and (5) to test hypotheses $1 \mathrm{a}, 1 \mathrm{~b}$, and $1 \mathrm{c}$, as follow (all variables information is on the appendix $\mathrm{A})$ :

$$
\begin{gathered}
O W N_{j}=a_{31}+b_{31} \text { EARN_TIMELY }+ \\
c_{31} \text { GROWTH }+c_{32} L O G \_A S E T_{j}+c_{33} L E V_{J} \\
+c_{34} \text { FIRM_AGE }_{j}+e_{j}
\end{gathered}
$$


AKRUAL: Jurnal Akuntansi, volume 9, nomor 2, April 2018,

$$
\begin{gathered}
I N D_{j}=a_{41}+b_{41} \quad \text { EARN_TIMELY } \\
c_{41} \text { GROWTH }+ \\
+c_{44} \text { FIRM_AGE }_{4}+e_{j} L O e_{j} A S E T_{j}+c_{43} L E V_{J} \\
\text { BOD }_{j}=a_{51}+b_{51} E A R N \_T I M E L Y_{j}+ \\
c_{51} \text { GROWTH }+c_{52} L O G_{-} A S E T_{j}+ \\
c_{53} L E V+c_{54} \text { FIRM_AGE }+e_{j}
\end{gathered}
$$

We hypothesized that there is negative relation between earnings timelines and corporate governance mechanism, so we expect that $b_{31}, b_{41}, b_{51}$ would be negative for Model 3, 4, and 5. From regression result of Model 3, 4, and 5, this study derived fitted value for OWN, IND, and BOD as independent variables value of Model 6, 7, and 8. Therefore, to test hypotheses 2a, 2b, and 2c, we use model (6), (7), and (8) as follow (the variables information is on the appendix A):

EARN_TIMELY $Y_{j}=d_{61}+e_{61} f v O W N_{j}+$ $f_{61}$ GROWTH $_{j} \quad+f_{62} L O G_{-} A S E T_{j}+f_{63} L E V_{j}$ $+f_{64} P A F_{j}+e_{j}$

$E A R N_{-}$TIMELY $_{j}=d_{71}+e_{71} f_{v I N D_{j}}+$ $f_{71} G R O W T H_{j}+f_{72} L O G_{-} A S E T_{j}+f_{73} L E V_{j}+$ $f_{74} P A F_{j}+e_{j}$

EARN_TIMELY $Y_{j}=d_{81}+e_{81} f v B O D_{j}+$ $f_{81} G R O W T H_{j}+f_{82} L O G_{-} A S E T_{j}+f_{83} L E V_{j}+$ $f_{84} P A F_{j}+e_{j}$
This study hypothesized that there is positive relation between corporate governance mechanism and earnings timelines, therefore $\mathrm{H} 2 \mathrm{a}, 2 \mathrm{~b}$ and $2 \mathrm{c}$ are accepted if the coefficient of fvOWN, fvIND, and fvBOD (e61, e71, e81) are positive.

All empirical models (Model 3, 4, 5, 6, 7, and 8) are tested using multiple linear regressions, but this study examines the classical assumption before testing the hypothesis in order to get the Best Linear Unbiased Estimator (BLUE) model. Since the research data type is cross section, this study only test the multicollinearity and heteroskedasticity.

\section{ANALYSIS AND DISCUSSION}

\section{Statistic Descriptive}

Statistic descriptive result of all variables is shown on Table 1, and all outlier had been

\begin{tabular}{|c|c|c|c|c|c|c|c|c|c|}
\hline & OWN & IND & BOD & $\begin{array}{l}\text { EARN_ } \\
\text { TIMEL } \\
\text { Y }\end{array}$ & $\begin{array}{l}\text { GROW } \\
\text { H }\end{array}$ & $\begin{array}{l}\text { LOG }_{-} \\
\text {ASET }\end{array}$ & LEV & $\begin{array}{l}\text { FIRM_ } \\
\text { AGE }\end{array}$ & PAF \\
\hline Mean & 0.6992 & 0.4284 & 4.3621 & 5.3728 & 0.1887 & 20.1851 & 0.5293 & 31.8714 & 0.4143 \\
\hline Median & 0.7451 & 0.3541 & 3 & 5.3095 & 0.1575 & 20.3164 & 0.5004 & 29.5 & 0 \\
\hline Maxi. & 0.9896 & 1 & 10.353 & 9.2857 & 1.3202 & 25.7479 & 1.9430 & 72 & 1 \\
\hline Min. & 0.0941 & 0 & 2 & 1.2381 & -0.6678 & 5.6371 & 0.0626 & 11 & 0 \\
\hline Std. Dev. & 0.1968 & 0.1948 & 1.9641 & 2.0833 & 0.2511 & 3.1646 & 0.3556 & 12.8693 & 0.4962 \\
\hline
\end{tabular}
treated with winzorizing technique. On average, the sample firms have timely earnings reporting, it showed from mean value of EARN_TIMELY is above 5 .

Table 1. Descriptive Statistic 
Arieftiara, Utama, Do Financial Reporting Quality...

Result of classical assumption test showed that there are no correlations among all variables tested (there is no multicollinearity) and from residual test showed that all variables are heterogeneous. Therefore, this study meets the classical assumption.

\section{Empirical Test Results}

The study obtains score from three composite metrics of earnings timelines as explained at variable operational definition section. This study takes only score for revenue slope and $\mathrm{R}^{2}$ value from Basu Model, and value of $\mathrm{R}^{2}$ from ERC model without consider the significance of those models. Furthermore, each score will be ranked based on percentile rank, and the value for earning timelines is average percentile rank for three metrics.
Relationship between earnings timelines (as an exogenous variable) and corporate governance mechanism (as an endogenous variable)

The summary of hypothesis 1a test result shown on Table 2. Table 2 showed the probability Fstatistic is significant (0.000); and value for $\mathrm{R}^{2}$ is $15.9 \%$. The result indicates that model 3 is adequate to predict relationship between earnings timelines and ownership concentration. Our result for EARN_TIMELY is not significant, this indicates that hypothesis 1a is not supported, this means that earnings timelines has no relation with ownership concentration.

Table 2. Result summary of earnings timelines regression on ownership concentration and various control variables.

\begin{tabular}{lccc} 
& $O W N_{j}=a_{31}+b_{31}$ & $E A R N_{-} T I M E L Y_{j}+c_{31} G R O W T H_{j}+c_{32} L O G_{-} A S E T_{j}+c_{33} L E V_{J}+c_{34} F I R M_{-} A G E_{j}+e_{j}(3)$ \\
\hline \multicolumn{1}{c}{ Variable } & Sign Predicted & Coefficient & \multicolumn{1}{c}{ Prob. t-statistic } \\
\hline Intercept & & 0.661037 & $0.0013^{* * * *}$ \\
EARN_TIMELY & H1a: - & 0.005202 & 0.6715 \\
GROWTH & & 0.0701 & 0.4796 \\
LOG_ASET & & -0.000256 & $0.0974^{*}$ \\
LEV & & 0.024499 & 0.725 \\
FIRM_AGE & -0.000338 & $0.0861^{*}$ \\
R-square & & \\
Prob. (F-statistic) & 0.0159 & & \\
$\mathrm{~N}$ & 0.0000 & & \\
\hline
\end{tabular}

Variables information is on appendix A.***Significant at 1\%;**Significant at 5\%; *Significant at $10 \%$ Source: processed data

Next we use Model 4 to test hypothesis $1 \mathrm{~b}$, the result showed on Table 3 . Table 3 shows that earnings timelines can explains the proportion of independent board at $18.38 \%$ with concerns to various control variable (significant at level 1\%). The value of coefficient EARN_TIMELY $\left(b_{41}\right)$ is -0.279378 as predicted. This means that the increasing firms' earnings timelines could lower the demand of independent board to all sample firms, ceteris 
AKRUAL: Jurnal Akuntansi, volume 9, nomor 2, April 2018,

paribus. Firm age is the only significant control variable (significant at level 10\%). According to the result, hypothesis $1 \mathrm{~b}$ is supported by data, which shows financial reporting quality (earnings timelines) negatively influence the proportion of independent board.

Table 3. Result summary of earnings timelines regression on proportion of independent board and various control variables.

$I N D_{j}=a_{41}+b_{41} E A R N_{-} T I M E L Y_{j}+c_{41} G_{1} O W T H_{j}+c_{42} L O G_{-} A S E T_{j}+c_{43} L E V_{J}+c_{44} F I R M_{-} A G E_{j}+e_{j}$

\begin{tabular}{lccr}
\hline \multicolumn{1}{c}{ Variabel } & Sign Predicted & Coefficient & Prob. t-statistic \\
\hline Intercept & & 0.430294 & $0.0074^{* * *}$ \\
EARN_TIMELY & H1b: - & -0.279378 & $0.0035^{* * *}$ \\
GROWTH & & -0.086328 & 0.3368 \\
LOG_ASET & & 0.004063 & $0.0567^{*}$ \\
LEV & & 0.067035 & 0.285 \\
FIRM_AGE & & 0.003223 & $0.0719^{*}$ \\
R-squared & 0.1838 & & \\
Prob(F-statistic) & 0.0000 & & \\
N & 131 & & \\
\hline
\end{tabular}

Variables information is on appendix A. ***Significant at $1 \%$; **Significant at $5 \%$; *Significant at $10 \%$ Source: processed data

We test hypothesis 1c using Model 5, the result showed on Table 4 . From Table 4 we can conclude that earnings timelines has no significant influence on board size even though has negative sign as predicted. Firm size as a control variable positively related to board size (significant at 5\%). According to the result, hypothesis $1 \mathrm{c}$ is not supported by the data, thus financial reporting quality is not affect board size.

Table 4. Result summary of earnings timelines regression on board size and various control variables.

\begin{tabular}{|c|c|c|c|}
\hline Variabel & Sign Predicted & Coefficient & Prob. t-statistic \\
\hline Intercept & & 0.897291 & 0.6253 \\
\hline EARN_TIMELY & H1c: - & -0.10286 & 0.3695 \\
\hline GROWTH & & -0.512327 & 0.5791 \\
\hline LOG_ASET & & 0.180857 & $0.0185 * *$ \\
\hline LEV & & -0.189438 & 0.7704 \\
\hline FIRM_AGE & & 0.017692 & 0.3273 \\
\hline R-squared & 0.1416 & & \\
\hline Prob(F-statistic) & 0.0075 & & \\
\hline $\mathrm{N}$ & 131 & & \\
\hline
\end{tabular}


Arieftiara, Utama, Do Financial Reporting Quality...

Relationship between corporate governance mechanism (as an exogenous variable) and earnings timelines (as endogenous variable)

We use multiple linear regression of Model 6 to test hypothesis $2 \mathrm{a}$. The result is showed on Table 5. The value of prob. F-statistic and $\mathrm{R}^{2}$ respectively are 0.0002 and $9.75 \%$, indicate that Model 6 is adequate to explains the relationship between ownership concentration and financial reporting quality. From Table 5, ownership concentration (OWN) has positive sign as predicted but not significant (probability tstatistic is 0.4677$)$. Firm size as control variable has positive relationship with financial reporting quality (significant at 10\%). According to the result, hypothesis $2 \mathrm{a}$ is not supported, so that ownership concentration has no influence to financial reporting quality.

Table 5. Result summary of ownership concentration regression on earnings timelines and various control variables. $E A R N_{-} T I M E L Y_{j}=d_{61}+e_{61} f v O W N_{j}+f_{61} G R O W T H_{j}+f_{62} L O G_{-} A S E T_{j}+f_{63} L E V_{j}+f_{64} P A F_{j}+e_{j}$

(6)

\begin{tabular}{|c|c|c|c|}
\hline Variable & Sign Predicted & Coefficient & Prob. t-statistic \\
\hline Intercept & & 7.485751 & $0.0002 * * *$ \\
\hline OWN & H2a: + & 0.972409 & 0.4677 \\
\hline GROWTH & & 0.47224 & 0.6362 \\
\hline LOG_ASET & & -0.143826 & $0.0827 *$ \\
\hline LEV & & 0.484904 & 0.4976 \\
\hline PAF & & -0.568593 & 0.3048 \\
\hline R-squared & 0.0975 & & \\
\hline Prob(F-statistic) & 0.0002 & & \\
\hline $\mathrm{N}$ & 131 & & \\
\hline
\end{tabular}

Next we test hypothesis $2 \mathrm{~b}$ using multiple linear regression of Model 7. The result is showed on Table 6, the value of prob. F-statistic and $\mathrm{R}^{2}$ respectively are 0.0006 and $14.49 \%$. This means that Model 7 can explains the relationship between proportion of independent board and financial reporting quality (measured by earnings timelines) with controlling GROWTH, LOG ASET, LEV and KAP.

Proportion of independent board (IND) has positive sign as predicted and significant at level $5 \%$. This means that the increasing of proportion of independent board then firm's earnings timelines will increase, ceteris paribus. Firm size (LOG_ASET) as control variable has positive relationship with financial quality reporting (significant at $10 \%$ ). According to the result, hypothesis $2 \mathrm{~b}$ is supported, so that proportion of independent board positively related to financial reporting quality. 
AKRUAL: Jurnal Akuntansi, volume 9, nomor 2, April 2018,

Table 6. Result summary of proportion of independent board regression on earnings timelines and various control variables

$E A R N \_T I M E L Y_{j}=d_{71}+e_{71} f v I N D_{j}+f_{71} G_{R O W T H_{j}}+f_{72} L O G \_A S E T_{j}+f_{73} L E V_{j}+f_{74} P A F_{j}+e_{j}$ (7)

\begin{tabular}{lccc}
\hline Variable & Sign Predicted & Coefficient & Prob. t-statistic \\
\hline Intercept & & 7.199133 & $0.0001^{* * *}$ \\
IND & H2b: + & 2.585201 & $0.0465^{* *}$ \\
GROWTH & & 0.881448 & 0.3701 \\
LOG_ASET & & -0.150151 & $0.0617^{*}$ \\
LEV & & 0.315925 & 0.6518 \\
PAF & 0.1449 & -0.571344 & 0.2689 \\
R-squared & 2.1705 & & \\
F-statistic & 0.0006 & & \\
Prob(F-statistic) & & \\
Variables information is on appendix A. ***Significant at 1\%; **Significant at 5\%; *Significant at $10 \%$ \\
Source: processed data
\end{tabular}

Our last test is hypothesis $2 \mathrm{c}$, we use multiple linear regression on Model 8. The result is showed on table 7. From table 7, the value of $\mathrm{R}^{2}$ is 0.6878 and prob. F-statistic is 0.0008 . It indicates that board size and control variables can explain financial reporting quality at $68.78 \%$ through Model 8.

Table 7. Result summary of board size regression on earnings timelines and various control variables $E A R N_{-} T I M E L Y_{j}=d_{81}+e_{81} f v B O D_{j}+f_{81} G_{R O W T H_{j}}+f_{82} L O G_{-} A S E T_{j}+f_{83} L E V_{j}+f_{84} P A F_{j}+e_{j}$ (8)

\begin{tabular}{lrrr}
\hline Variable & Sign Predicted & Coefficient & Prob. t-statistic \\
\hline Intercept & H2c: + & 172.842 & $0.0096^{* * *}$ \\
BOD & & 6.987124 & $0.0166^{* *}$ \\
GROWTH & & -4.104051 & 0.6945 \\
LOG_ASET & -9.246313 & $0.0121^{* *}$ \\
LEV & 8.732738 & 0.527 \\
PAF & 0.6878 & 13.28168 & $0.0278^{* *}$ \\
R-squared & 0.0008 & & \\
Prob(F-statistic) & 131 & & \\
N & & \\
Variables information is on appendix A. ***Significant at $1 \% ; * *$ Significant at $5 \% ; *$ Significant at $10 \%$ \\
Source: processed data
\end{tabular}

\section{Coefficient of board size (BOD) is} significant positive (as predicted) at level 5\%. It indicates that the increasing of board size will result on the increasing of earnings timelines, ceteris paribus. Public accounting firm (PAF) and firm size (LOG_ASET) as control variables has positive relation with financial reporting quality (significant at level 10\%). According to the result, hypothesis $2 \mathrm{c}$ is supported by data.

\section{Sensitivity analysis}

To test the sensitivity of main result, we change the variable measures. We change previous 
Arieftiara, Utama, Do Financial Reporting Quality...

earnings timelines measure (average percentile rank of 3 metrics) with value of each metrics separately. Then reexamine Model 3, 4, 5 and 6 using multiple linear regressions. The result is consistent with the main result.

\section{CONCLUSIONS}

This research is aimed to investigate the recursive simultaneous relationship between financial reporting quality and corporate governance mechanism in Indonesia context. We use earnings timelines as measure of financial reporting quality. Based on Bushman et al. (2004), earnings timelines is average percentile rank of three metrics (i.e. REV_SLOPE; REV_R ${ }^{2}$; and ERC_R ${ }^{2}$ ). We use ownership concentration, proportion of independent board and board size as measures of corporate governance mechanism.

This study has three findings, first, there is no recursive simultaneous relationship between earnings timelines and ownership concentration. Earnings timelines is not affect ownership concentration, vice a versa. Second, there is a recursive simultaneous relationship between earnings timelines and proportion of independent board. Earnings timelines affects proportion of independent board, in the other side, proportion of independent board also affects earnings timelines. Finally, there is a relation between earnings timelines and board size, but this relation is not recursive simultaneous. This is due to earnings timelines affects board size, on the contrary, board size is not affect earnings timelines.

The findings are robust by sensitivity analysis results. The limitation of this study is we are not considered the significance of three metrics (Basu and ERC model) to obtain the component value of earnings timelines. This is due to only a small number of sample firms that have significant metrics (not more than 5 firms). However, we have examined this sample firm with significant metrics, and the result is not better than full sample's result.

Future research could expand the period of data especially for compute earning timelines variable. This will avoid near singular metrics occurs. Besides that, future research could use different industry as sample firm.

\section{REFERENCES}

Adams, R. B., \& Ferreira, D. (2007). A Theory of Friendly Boards. The Journal of Finance, 62(1), 217-250. DOI: doi:10.1111/j.15406261.2007.01206.x

Alimehmeti, G., \& Paletta, A. (2012). Ownership concentration and effects over firm performance: Evidences from Italy. European Scientific Journal, ESJ, 8(22).

Armstrong, C. S., Guay, W. R., \& Weber, J. P. (2010). The role of information and financial reporting in corporate governance and debt contracting. Journal of Accounting and Economics, 50(2-3), 179-234. DOI: doi:10.1016/j.jacceco.2010.10.001

Ball, R., \& Shivakumar, L. (2005). Earnings quality in UK private firms: comparative loss recognition timeliness. Journal of Accounting and Economics, 39(1), 83-128. doi:10.1016/j.jacceco.2004.04.001 
AKRUAL: Jurnal Akuntansi, volume 9, nomor 2, April 2018,

Beatty, A., Ramesh, K., \& Weber, J. (2002). The importance of accounting changes in debt contracts: the cost of flexibility in covenant calculations. Journal of Accounting and Economics, 33(2), 205-227. doi:10.1016/s0165-4101(02)00046-0

Beatty, A., Ramesh, K., \& Weber, J. (2002). The importance of accounting changes in debt contracts: the cost of flexibility in covenant calculations. Journal of Accounting and Economics, 33(2), 205-227. DOI: doi:10.1016/s0165-4101(02)00046-0

Burgstahler, D. C., Hail, L., \& Leuz, C. (2006). The Importance of Reporting Incentives: Earnings Management in European Private and Public Firms. The Accounting Review, 81(5), 983-1016. DOI: doi:10.2308/accr. 2006.81.5.983

Bushman, R., Chen, Q., Engel, E., \& Smith, A. (2004). Financial accounting information, organizational complexity and corporate governance systems. Journal of Accounting and Economics, 37(2), 167-201. DOI: doi:10.1016/j.jacceco.2003.09.005

Chan, K. C., \& Li, J. (2008). Audit Committee and Firm Value: Evidence on Outside Top Executives as Expert-Independent Directors. Corporate Governance: An International Review, 16(1), 16-31. doi:10.1111/j.14678683.2008.00662.x

Chi, L.-C. (2009). Do transparency and disclosure predict firm performance? Evidence from the Taiwan market. Expert Systems with Applications, 36(8), 1119811203. DOI: doi:10.1016/j.eswa.2009.02. 099

Claessens, S., Djankov, S., \& Lang, L. H. . (2000). The separation of ownership and control in East Asian Corporations. Journal of Financial Economics, 58(1-2), 81-112. DOI: doi:10.1016/s0304-405x(00)00067-2

Dechow, P. M., \& Dichev, I. D. (2002). The Quality of Accruals and Earnings: The Role of Accrual Estimation Errors. The Accounting Review, 77(s-1), 35-59. DOI: doi:10.2308/accr.2002.77.s-1.35
Dimitropoulos, P. E., \& Asteriou, D. (2010). The effect of board composition on the informativeness and quality of annual earnings: Empirical evidence from Greece. Research in International Business and Finance, 24(2), 190-205. DOI: doi:10.1016/j.ribaf.2009.12.001

Fama, E. F., \& Jensen, M. C. (1983). Separation of Ownership and Control. The Journal of Law and Economics, 26(2), 301-325. DOI: doi:10.1086/467037

Fanani, Z. (2009). Kualitas Pelaporan Keuangan: Berbagai Faktor Penentu Dan Konsekuensi Ekonomis. Jurnal Akuntansi Dan Keuangan Indonesia, 6(1), 20-45. DOI: doi:10.210 02/jaki.2009.02

Felo, A. J., Krishnamurthy, S., \& Solieri, S. A. (2003). Audit Committee Characteristics and the Perceived Quality of Financial Reporting: An Empirical Analysis. SSRN Electronic Journal. DOI: doi:10.2139/ssrn. 401240

Givoly, D., Hayn, C. K., \& Katz, S. P. (2010). Does Public Ownership of Equity Improve Earnings Quality? The Accounting Review, 85(1), 195-225. DOI: doi:10.2308/accr. 2010.85.1.195

Jung, K., \& Kwon, S. Y. (2002). Ownership structure and earnings informativeness. The International Journal of Accounting, 37(3), 301-325. DOI: doi:10.1016/s0020-7063 (02)00173-5

Kusumawati, D. N., \& Riyanto, B. (2005). Corporate governance dan kinerja: analisis pengaruh compliance reporting dan struktur dewan terhadap kinerja. Simposium Nasional Akuntansi, 8, 248-261.

La Porta, R., Lopez-De-Silanes, F., Shleifer, A., \& Vishny, R. (2002). Investor Protection and Corporate Valuation. The Journal of Finance, $\quad 57(3), \quad 1147-1170 . \quad$ DOI: doi:10.1111/1540-6261.00457

Linck, J., Netter, J., \& Yang, T. (2008). The determinants of board structure ${ }^{2}$. Journal of Financial Economics, 87(2), 308-328. DOI: doi:10.1016/j.jfineco.2007.03.004 
Nuryaman (2008), "Pengaruh Konsentrasi Kepemilikan, Ukuran Perusahaan, dan Mekanisme Corporate Governance Terhadap Manajemen Laba", Paper Presented at the SNA 11th Pontianak.

Nuryaman, N. (2009). Pengaruh Konsentrasi Kepemilikan, Ukuran Perusahaan, Dan Mekanisme Corporate Governance Terhadap Pengungkapan Sukarela. Jurnal Akuntansi Dan Keuangan Indonesia, 6(1), 89-116. DOI: doi:10.21002/jaki.2009.05

OECD. (1999), "Benchmarking KnowledgeBased Economies", OECD Science, Technology and Industry Scoreboard 1999.

Petra, S. T. (2006). The Effects of Corporate Governance on the Informativeness of Earnings. Economics of Governance, 8(2), 129-152. DOI: doi:10.1007/s10101-0060018-8

Rachmawati, A., \& Triatmoko, H. (2007), "Analisis Faktor-Faktor yang Mempengaruhi Kualitas Laba dan Nilai Perusahaan", Paper Presented at the SNA 10th Makasar.

Siregar, S. V. N., \& Utama, S.( 2006). Pengaruh Struktur Kepemilikan, Ukuran Perusahaan, dan Praktek Corporate Governance terhadap Pengelolaan Laba (Earnings Management), Journal Riset Akuntansi Indonesia Vol 9 No. 3. Hal 307, 326.

Sloan, R. G. (2001). Financial accounting and corporate governance: a discussion. Journal of Accounting and Economics, 32(1-3), 335347. DOI: doi:10.1016/s0165-4101(01)000 39-8

Suranta, E., \& Midiastuty, P. P. (2005). Corporate Governance, Earnings, dan Return Saham. Simposium Riset Ekonomi II.

Susanto, S., \& Siregar, S. V. (2012). Corporate Governance, Kualitas Laba, dan Biaya Ekuitas: Studi Empiris Perusahaan Manufaktur yang Terdaftar di Bursa Efek Indonesia Tahun 2009. Simposium Nasional Akuntansi XV.
Vafeas, N. (2000). Board structure and the informativeness of earnings. Journal of Accounting and Public Policy, 19(2), 139160. DOI: doi:10.1016/s0278-4254(00)00 006-5

Wardhani, R., \& Joseph, H. (2010). Karakteristik Pribadi Komite Audit dan Praktik Manajemen Laba. Simposium Nasional Akuntansi XIII, 1-26.

Wawo, A. (2010), "Pengaruh Corporate Governance dan Konsentrasi Kepemilikan Terhadap Daya Informasi Akuntansi”, Paper Presented at SNA 13th Purwokerto.

\begin{tabular}{|c|c|}
\hline Appendix & \\
\hline $\mathrm{OWN}_{\mathrm{j}}$ & $\begin{aligned}= & \text { largest percentage of share } \\
& \text { ownership of firm } j \text { on } 2015\end{aligned}$ \\
\hline $\mathrm{IND}_{\mathrm{j}}$ & $\begin{array}{l}=\text { the proportion of independent } \\
\text { board of firm } j \text { (maximum } 9 \\
\text { years become an independent } \\
\text { board member in the same } \\
\text { firm) divided by total board } \\
\text { member }\end{array}$ \\
\hline $\mathrm{BOD}_{\mathrm{j}}$ & $\begin{array}{l}=\text { board size, that is total of } \\
\text { board member of firm } \mathrm{j} \text { on } \\
\\
2015 .\end{array}$ \\
\hline EARN_TIMELY $_{j}$ & 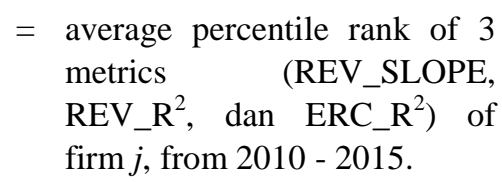 \\
\hline LOG_ASET $_{j}$ & $\begin{array}{l}=\text { logaritma natural of total } \\
\text { assets firm } j \text { on } 2015 .\end{array}$ \\
\hline $\mathrm{LEV}_{\mathrm{j}}$ & $\begin{aligned}= & \text { leverage, total debt divided by } \\
& \text { total assets of firm } j \text { on } 2015 .\end{aligned}$ \\
\hline FIRM_AGE & $\begin{array}{l}=\text { length period of operation of } \\
\text { firm } j \text { (years). }\end{array}$ \\
\hline GROWTHj & $\begin{array}{l}=\text { firm } j \text { growth, measured by } \\
\text { growth of net sales } 2015 \text { (net } \\
\text { sales changes divided by lag } \\
\text { net sales). }\end{array}$ \\
\hline $\mathrm{PAF}_{\mathrm{j}}$ & $\begin{array}{l}=\text { dummy variable of public } \\
\text { accountant firms, } 1 \text { if this } \\
\text { public accountant firm } \\
\text { affiliates with big four firm, } 0 \\
\text { otherwise. }\end{array}$ \\
\hline
\end{tabular}

